Research Article

Journal of Extension Education

Vol. 30 No. 4, 2018

DOI:https://doi.org/10.26725/JEE.2018.4.30.6157-6164

\title{
Food Consumption Pattern among School Going Children in a Rural Area of Kerala
}

\author{
K.L.Blossom ${ }^{1}$, Shilpa Jose ${ }^{2}$ and Daisy C. Kappen ${ }^{3}$
}

\begin{abstract}
A study was conducted to assess the socioeconomic details and food consumption pattern of school children in a rural community. A total of 100 children in the age group of 10-12 years in Ernakulam district of Kerala was selected using simple random sampling. Interview method with the help of structured and pretested schedule was used to collect the data. The frequency of consumption of different foods was assessed using a food frequency questionnaire. The findings revealed high consumption of rice, milk \& milk products, sugar \& jaggery, fats \& edible oils, medium consumption of vegetables \& non vegetarian items, and low consumption of pulses, nuts, oil seeds \& fruits. This indicates the poor socioeconomic status prevailing in the area under study.
\end{abstract}

Keywords: School children; Socioeconomic status; Food consumption; Food frequency; Kerala

\section{INTRODUCTION}

School age is a dynamic period of growth and development forming a strong foundation for good health and productive adult life. School children grow significantly, but at slower rate. Their nutritional needs are high and critical and hence appropriate dietary intake is critical during this period as it provides the essential nutrients needed for growth as well as educational achievements. Though the Central and State Governments are trying to overcome malnutrition among children through various household oriented programmes, the problem is still existing to a large extent in the country. The data on the food consumption pattern of children in rural areas will be useful for the government to monitor the food distribution system and make sure that it reaches the targeted population. Hence, the present study was proposed in this direction with the following objectives.

- To study the socioeconomic details of school going children.

- To collect data on the food habits and preferences of the children 3.To assess the frequency of consumption of different foods

\section{METHODOLOGY}

The study was purposively conducted at Valakom village near Muvattupuzha in Ernakulam district of Kerala. The village population consisted mainly of daily wage workers in the agricultural sector which

1. Assistant Professor, Department of Fish Processing Technology and 3. Associate Professor \& Director of Extension, Kerala University of Fisheries and Ocean Studies, Ernakulam, Kerala 2. Assistant Professor, Department of Home Science, St.Teresa's College, Mahatma Gandhi University, Kottayam, Kerala

Received : 23-11-2018; Accepted : 06-03-2019 
belonged to BPL (Below Poverty Line) families. The population mainly resided in colonies with unconcreted houses and little property. The samples were randomly selected from the school register which comprised 100 school going children of 10 - 12 years from both sexes.

A pre-prepared interview schedule was used in order to collect the required information about the socioeconomic status and food consumption pattern of the families. A food frequency questionnaire was used to collect information about the frequency of each food item consumed for the preceding month. The data were statistically analysed using percentage analysis.

Table 1.

Socio-economic Details of the School Children

\begin{tabular}{|c|c|c|c|}
\hline $\begin{array}{l}\text { SI. } \\
\text { No. }\end{array}$ & $\begin{array}{c}\text { General } \\
\text { Information }\end{array}$ & Number & $\begin{array}{c}\text { Percen } \\
\text { tage }\end{array}$ \\
\hline \multirow[t]{3}{*}{1} & Sex & & \\
\hline & Boys & 47 & 47 \\
\hline & Girls & 53 & 53 \\
\hline \multirow[t]{4}{*}{2} & Age & & \\
\hline & 10 & 60 & 60 \\
\hline & 11 & 30 & 30 \\
\hline & 12 & 10 & 10 \\
\hline \multirow[t]{4}{*}{3} & Religion & & \\
\hline & Christian & 40 & 40 \\
\hline & Hindu & 56 & 56 \\
\hline & Muslim & 4 & 4 \\
\hline \multirow[t]{4}{*}{4} & Birth order & & \\
\hline & $1-2$ & 87 & 87 \\
\hline & $3-4$ & 12 & 12 \\
\hline & $5-6$ & 1 & 1 \\
\hline
\end{tabular}

\begin{tabular}{|c|c|c|c|}
\hline $\begin{array}{l}\text { SI. } \\
\text { No. }\end{array}$ & $\begin{array}{c}\text { General } \\
\text { Information }\end{array}$ & Number & $\begin{array}{c}\text { Percen } \\
\text { tage }\end{array}$ \\
\hline 5 & $\begin{array}{l}\text { Education of the } \\
\text { father } \\
\text { Illiterate } \\
\text { Primary school level } \\
\text { High school level } \\
\text { Graduate level } \\
\end{array}$ & $\begin{array}{c}3 \\
26 \\
67 \\
4 \\
\end{array}$ & $\begin{array}{c}3 \\
26 \\
67 \\
4\end{array}$ \\
\hline 6 & $\begin{array}{l}\text { Education of the } \\
\text { mother } \\
\text { Illiterate } \\
\text { Primary school level } \\
\text { High school level } \\
\text { Graduate level }\end{array}$ & $\begin{array}{c}1 \\
19 \\
78 \\
2\end{array}$ & $\begin{array}{c}1 \\
19 \\
78 \\
2\end{array}$ \\
\hline 7 & $\begin{array}{l}\text { Occupation of the } \\
\text { father } \\
\text { Coolie } \\
\text { Agricultural } \\
\text { labourer } \\
\text { Daily wages } \\
\text { (Employed for } \\
\text { whole day) } \\
\text { Clerk }\end{array}$ & $\begin{array}{c}46 \\
2\end{array}$ & $\begin{array}{l}27 \\
25\end{array}$ \\
\hline 8 & $\begin{array}{l}\text { Occupation of the } \\
\text { mother } \\
\text { Sweeper } \\
\text { Agricultural } \\
\text { labourer } \\
\text { Daily wages } \\
\text { House maid }\end{array}$ & $\begin{array}{c}2 \\
14 \\
80\end{array}$ & $\begin{array}{c}4 \\
2 \\
14 \\
80\end{array}$ \\
\hline 9 & $\begin{array}{l}\text { Monthly income (Rs.) } \\
\text { Low(Rs.2000- } \\
3000) \\
\text { Middle (Rs.3000- } \\
4000) \\
\text { High (Rs.4000- } \\
5000)\end{array}$ & 24 & $\begin{array}{l}65 \\
24 \\
11\end{array}$ \\
\hline
\end{tabular}




\begin{tabular}{|c|l|c|c|}
\hline $\begin{array}{r}\text { Sl. } \\
\text { No. }\end{array}$ & \multicolumn{1}{|c|}{$\begin{array}{c}\text { General } \\
\text { Information }\end{array}$} & Number & $\begin{array}{c}\text { Percen } \\
\text { tage }\end{array}$ \\
\hline 10 & $\begin{array}{l}\text { Transportation to } \\
\text { school }\end{array}$ & & \\
& Walking & 50 & 50 \\
& Bicycle & 7 & 7 \\
& Public transport & 43 & 43 \\
\hline 11 & Source of light for & & \\
& studying & 5 & 5 \\
& Candle & 85 & 85 \\
Tube light & 10 & 10 \\
\hline
\end{tabular}

\section{FINDINGS AND DISCUSSION}

\section{Socio-economic Details}

The socio-economic conditions are considered as the most important factor influencing the food purchasing power of the families which in turn affect the nutritional status. Poor socioeconomic conditions are the root causes for most of the nutritional problems observed in our country. Socioeconomic details in the present study included general information about subjects and are furnished in Table 1.

It was noted that the subjects consisted of 47 per cent boys and 53 per cent girls. The subjects were of the ages ten (60\%), eleven (30\%) and twelve (10\%). Details pertaining to religion revealed that majority of them were Hindus (56\%). Regarding the birth order of the children, majority $(87 \%)$ were either first or second borns. Educational status of father indicated that majority (67\%) had high school qualification and only three per cent were illiterate. Majority (78\%) of the mothers also had high school education and only one per cent was illiterate. Literacy is an important demographic characteristic which is an indicator of level of advancement of people. Bose (2011) also reported Kerala as the most literate state with a higher literacy of 93.9 per cent as per the 2011 Census report of India.

The occupational status of family members is an important factor influencing the food purchasing pattern and thus the health and nutritional status of family members. The results indicated that majority $(46 \%)$ of the fathers were daily wage workers whereas 80 per cent of the mothers were house maids. Employed mothers were found to be more than employed fathers. This might be due to the increased wages of men when compared to women. Most of the women were engaged in household activities and if the women are involved in income generating activities it will improve the family income which in turn improve the food and nutritional security of children. Regarding the economic status of the family, the monthly income of 65 per cent of the families was in the range of Rs.2000-3000. Though there is a hike in the income of daily wage workers, the low income of the parents may be due to irregularity in the employment of fathers and unemployment of mothers. Ramaraju (2015) also reported low monthly income among the BPL families in Kerala. Fifty per cent of the student's mode of transportation to school was by walking and 43 per cent depended on public transport. Eighty five per cent of the subjects used tube light for studying. Even though they are residing in colonies, electricity facilities were found to be better due to the facilities provided by the 
Table 2.

Food Habits of the Children

\begin{tabular}{|c|c|c|c|}
\hline $\begin{array}{l}\text { Sl. } \\
\text { No. }\end{array}$ & Categories & Number & $\begin{array}{c}\text { Percen } \\
\text { tage }\end{array}$ \\
\hline \multirow[t]{4}{*}{1} & $\begin{array}{l}\text { Regular time for } \\
\text { food }\end{array}$ & & \\
\hline & Often & 47 & 47 \\
\hline & Sometimes & 67 & 67 \\
\hline & Never & 7 & 7 \\
\hline \multirow[t]{3}{*}{2} & Skips breakfast & & \\
\hline & Yes & 13 & 13 \\
\hline & No & 87 & 87 \\
\hline \multirow[t]{3}{*}{3} & $\begin{array}{l}\text { Takes packed lunch } \\
\text { to school }\end{array}$ & & \\
\hline & Yes & 46 & 46 \\
\hline & No & 54 & 54 \\
\hline \multirow[t]{4}{*}{4} & Lunch items taken & & \\
\hline & Rice and vegetables & 98 & 98 \\
\hline & Breakfast items & 1 & 1 \\
\hline & Tapioca & 1 & 1 \\
\hline \multirow[t]{4}{*}{5} & $\begin{array}{l}\text { Types of snacks } \\
\text { taken }\end{array}$ & & \\
\hline & Sweet items & 14 & 14 \\
\hline & Savoury items & 44 & 44 \\
\hline & Biscuits & 24 & 24 \\
\hline \multirow[t]{3}{*}{6} & $\begin{array}{l}\text { Intake of raw fruits } \\
\text { and vegetables }\end{array}$ & & \\
\hline & Yes & 88 & 88 \\
\hline & No & 12 & 12 \\
\hline \multirow[t]{3}{*}{7} & Use of iodized salt & & \\
\hline & Yes & 49 & 49 \\
\hline & No & 51 & 51 \\
\hline
\end{tabular}

\begin{tabular}{|c|l|c|c|}
\hline $\begin{array}{r}\text { Sl. } \\
\text { No. }\end{array}$ & \multicolumn{1}{|c|}{ Categories } & Number & $\begin{array}{c}\text { Percen } \\
\text { tage }\end{array}$ \\
\hline 8 & $\begin{array}{l}\text { Oil used for } \\
\text { cooking } \\
\text { Coconut }\end{array}$ & 78 & 78 \\
& Palmolein & 8 & 8 \\
\hline 9 & Both & 14 & 14 \\
\hline & Consumption of & & \\
water per day & (150ml/glass) & 55 & 55 \\
<8 glasses & 29 & 29 \\
8-10 glasses & 16 & 16 \\
\hline 10 glasses & & \\
\hline
\end{tabular}

Government for BPL families. However, the low socio-economic status of the subjects is the result of their impoverished environment in terms of low educational and occupational status.

\section{Food Habits and Preferences}

Food habits may be defined as the way in which individuals in response to social and cultural pressures, select, consume and utilize portions of the available food supply. Food Table 3.

Food Preferences of the Children

\begin{tabular}{|c|l|c|c|}
\hline $\begin{array}{r}\text { Sl. } \\
\text { No. }\end{array}$ & \multicolumn{1}{|c|}{ Categories } & Number & $\begin{array}{c}\text { Percent } \\
\text { (\%) }\end{array}$ \\
\hline 1 & $\begin{array}{l}\text { Foods preferred } \\
\text { Ready to eat } \\
\text { Homemade }\end{array}$ & 7 & 7 \\
\hline 2 & $\begin{array}{l}\text { Reason for the } \\
\text { preference } \\
\text { Convenience } \\
\text { Taste }\end{array}$ & 4 & 93 \\
\hline
\end{tabular}


Food Consumption Pattern among School Going Children in a Rural Area of Kerala

\begin{tabular}{|c|c|c|c|}
\hline $\begin{array}{l}\text { Sl. } \\
\text { No. }\end{array}$ & Categories & Number & \begin{tabular}{|c} 
Percent \\
$(\%)$
\end{tabular} \\
\hline \multirow[t]{4}{*}{3} & Enjoys eating with & & \\
\hline & Friends & 11 & 11 \\
\hline & Family members & 86 & 86 \\
\hline & Alone & 3 & 3 \\
\hline \multirow[t]{7}{*}{4} & $\begin{array}{l}\text { Food preferred for } \\
\text { breakfast }\end{array}$ & & \\
\hline & Uppuma & 10 & 10 \\
\hline & Tapioca & 6 & 6 \\
\hline & Puttu & 20 & 20 \\
\hline & Idli & 39 & 39 \\
\hline & Dosa & 24 & 24 \\
\hline & Rice & 1 & 1 \\
\hline \multirow[t]{6}{*}{5} & $\begin{array}{l}\text { Food preferred as } \\
\text { evening snack }\end{array}$ & & \\
\hline & $\begin{array}{l}\text { Home made } \\
\text { snacks }\end{array}$ & 73 & 73 \\
\hline & Bakery items/ & & \\
\hline & biscuits & 16 & 16 \\
\hline & Only tea & 6 & 6 \\
\hline & Only milk & 5 & 5 \\
\hline \multirow[t]{4}{*}{6} & $\begin{array}{l}\text { Food preferred for } \\
\text { dinner }\end{array}$ & & \\
\hline & Rice & 89 & 89 \\
\hline & Chappathi & 2 & 2 \\
\hline & Kanji & 9 & 9 \\
\hline \multirow[t]{5}{*}{7} & Taste preferred & & \\
\hline & Spicy & 22 & 22 \\
\hline & Fried & 13 & 13 \\
\hline & Sweet & 64 & 64 \\
\hline & Salty & 1 & 1 \\
\hline \multirow[t]{4}{*}{8} & $\begin{array}{l}\text { Influencing basis } \\
\text { regarding food } \\
\text { preferences }\end{array}$ & & \\
\hline & Parents & 76 & 76 \\
\hline & Peers & 7 & 7 \\
\hline & Advertisements & 17 & 17 \\
\hline
\end{tabular}

\begin{tabular}{|c|l|c|c|}
\hline $\begin{array}{r}\text { SI. } \\
\text { No. }\end{array}$ & \multicolumn{1}{|c|}{ Categories } & Number & $\begin{array}{c}\text { Percent } \\
\text { (\%) }\end{array}$ \\
\hline 9 & Information & & \\
& sources about \\
food & & \\
& Newspaper & 13 & 13 \\
& Radio & 11 & 11 \\
& Television & 56 & 56 \\
& Magazines & 20 & 20 \\
\hline 10 & Taking outside & & \\
& food & & \\
& Yes & 59 & 59 \\
& No & 41 & 41 \\
\hline
\end{tabular}

preferences is the selection of food items from choices available among acceptable foods. Food habits and preferences are learnt, acquired and finally become a part of oneself. The results of the food habits (Table 2) and preferences (Table 3 ) of the selected subjects are given below.

With respect to food habits, 47 per cent of the children had food at regular time. Breakfast was not consumed regularly by 13 per cent of the children which may be due to unavailability at home. It was found that 54 per cent of the children had lunch at the school itself which is mainly due to the availability of lunch at school provided by the government for Government schools. Remaining (46\%) were to have it from home. Rice and vegetables was the packed lunch taken by 98 per cent of the subjects. Since the BPL families used to get rice or wheat at the rate of Rs. $1 / \mathrm{kg}$ through the PDS in Kerala, they preferred so. This 
indicates the effective utilization of the Public Distribution System prevalent in the state of Kerala by the BPL families.

Details pertaining to the consumption of snacks in between meals were found to be among 82 per cent of the children. Savoury items like chips, vada, puffs etc. were preferred as snacks by 44 per cent of the subjects followed by biscuits (24\%) and sweets (14\%). A study on the dietary habits of school children in Pune observed snacks, fast food and processed food as most preferred items (Mukherjee and Chaturvedi, 2017). Consumption of raw fruits and vegetables was noticed among 88 per cent of the children which may be those available in their locality like guava, papaya, mango etc.

It was found that 93 per cent preferred homemade food. The reason for their preference was mainly the taste factor. Majority (86\%) of them enjoyed eating food with their family members. When enquired about favourite breakfast items, many of takers were for idli (39\%) and dosai (24\%).
Majority (73\%) of the children preferred homemade snacks and the taste they liked mostly was sweet (64\%) and spicy (22\%). Rice (89\%) was preferred for dinner than chapathi (2\%). Majority (76\%) were influenced by the food preferences of their parents. Regarding the information sources about food, 56 per cent were influenced by television and 20 per cent by magazines. Food advertising may result in unhealthy eating habits which could be due to taste of the advertised products. The intake of food from outside was seen among 59 per cent of children which indicates the ever-growing trend of children preferring processed food and sweetened carbonated beverages.

\section{Food frequency}

This method involves assessment of the frequency of consumption of different foods using a food frequency questionnaire.

The economic status of the families and the local availability of food items are the two important factors which influence the frequency of use of various food items

Table 4.

Frequency Consumption of Various Foods

\begin{tabular}{|c|l|c|c|c|c|}
\hline $\begin{array}{c}\text { Sl. } \\
\text { No. }\end{array}$ & \multicolumn{1}{|c|}{ Food items } & $\begin{array}{c}\text { High } \\
\text { Atleast once } \\
\text { a day (\%) }\end{array}$ & $\begin{array}{c}\text { Medium } \\
\text { 1-6 times } \\
\text { a week (\%) }\end{array}$ & $\begin{array}{c}\text { Low } \\
\text { Less than } \\
\text { one week(\%) }\end{array}$ & Never (\%) \\
\hline 1 & Rice & 100.00 & - & - & - \\
\hline 2 & $\begin{array}{l}\text { Other cereal or } \\
\text { cereal products }\end{array}$ & 2.50 & 47.50 & 50.50 & 1.50 \\
\hline 3 & Pulses & 1.00 & 59.02 & 100.00 & - \\
\hline 4 & Leafy vegetables & 1.00 & 61.70 & 53.25 & - \\
\hline
\end{tabular}


Food Consumption Pattern among School Going Children in a Rural Area of Kerala

\begin{tabular}{|c|l|c|c|c|c|}
\hline $\begin{array}{c}\text { SI. } \\
\text { No. }\end{array}$ & \multicolumn{1}{|c|}{ Food items } & $\begin{array}{c}\text { High } \\
\text { Atleast once } \\
\text { a day (\%) }\end{array}$ & $\begin{array}{c}\text { Medium } \\
1-6 \text { times } \\
\text { a week (\%) }\end{array}$ & $\begin{array}{c}\text { Low } \\
\text { Less than } \\
\text { one week(\%) }\end{array}$ & Never (\%) \\
\hline 5 & $\begin{array}{l}\text { Roots and } \\
\text { tubers }\end{array}$ & 26.30 & 59.20 & 27.20 & 2.0 \\
\hline 6 & $\begin{array}{l}\text { Other } \\
\text { vegetables }\end{array}$ & 1.00 & 68.30 & 31.50 & - \\
\hline 7 & $\begin{array}{l}\text { Nuts and oil } \\
\text { seeds }\end{array}$ & 2.00 & 4.30 & 95.30 & - \\
\hline 8 & Fruits & 1.00 & 43.10 & 56.60 & 1.00 \\
\hline 9 & $\begin{array}{l}\text { Fish and other } \\
\text { seafoods }\end{array}$ & - & 51.80 & 47.00 & 5.00 \\
\hline 10 & $\begin{array}{l}\text { Meat and } \\
\text { poultry }\end{array}$ & 2.00 & 57.50 & 41.50 & - \\
\hline 11 & $\begin{array}{l}\text { Milk and milk } \\
\text { products }\end{array}$ & 87.00 & 8.00 & 5.00 & - \\
\hline 12 & $\begin{array}{l}\text { Fats and edible } \\
\text { oils }\end{array}$ & 97.00 & 1.00 & 2.00 & - \\
\hline 13 & Sugar & 50.00 & 28.00 & 35.00 & 2.00 \\
\hline 14 & $\begin{array}{l}\text { Condiments and } \\
\text { spices }\end{array}$ & 99.00 & - & 1.00 & - \\
\hline
\end{tabular}

in their diet. It was found that all the children (100\%) had high consumption of rice The findings revealed high consumption of rice., milk and milk products., sugar and jaggery., fats and edible oils., medium consumption of vegetables and non vegetarian items., and low consumption of nuts and oil seeds and fruits. Though majority of children have the habit of taking fruits, the frequency of consumption was found to be low. Studies conducted by Gharib and Rasheed (2011) and Latheef (2011) also observed almost similar dietary pattern among school children and labour households respctively.

\section{CONCLUSION}

The study revealed low socioeconomic conditions which are considered as the root cause for most of the nutritional problems observed in our country. Precise information on the food consumption pattern of children is essential not only for assessing the nutritional status of the children but also for elucidating the food needs of the children at regional and national levels. Though we have attained food security, nutrition security has not yet been achieved. Nutritional awareness programmes should become a part of all developmental 
activities. Since the study has revealed that intake of vegetables and fruits is found to be low among children, importance of balanced diet and nutrition gardening in homesteads should be encouraged for achieving self sufficiency in case of vegetables and fruits.

\section{REFERENCES}

Bose, A. (2011). Census of India 2011: some highlights. Yojana, 55, 5-9.

Gharib, N., \& Rasheed, P. (2011). Energy and macronutrient intake and dietary pattern among school children in Bahrain: a crosssectional study. Nutrition Journal, 10,1-12.
Latheef, N. (2011). Food and nutrition security of paddy cultivators of Kaliyoor panchayat Unpublished MSc (Home Science) thesis, Kerala Agricultural University, Thrissur, $81 p$.

Mukherjee, R., \& Chaturvedi, S. (2017). A study of the dietary habits of school children in Pune city, Maharashtra, India. International Journal of Community Medicine and Public Health, 4(2), 593-597.

Ramaraju, A. (2015). Health insurance scheme for low income groups in India with a focus on urban poor in Cochin. International Journal of Marketing and Human Resource Management, 6(1), 55-70. 